status of the employee whom he was replacing, this might again result in some new employees receiving greater seniority than some non-striking old employees. Similarly, any attempt to remedy this last defect by giving non-striking old employees preference over new replacements would necessarily be open to the objections already voiced ${ }^{73}$ with regard to inducing and rewarding non-striking old employees at the expense of the strikers. Thus, in addition to the strong policy arguments that may be made against superseniority plans, it would appear that such plans, if critically analyzed in the light of the equities and the practical problems involved, also pose great, if not insuperable, technical and legal problems of implementation.

The foregoing analysis suggests that strike superseniority, with its tendency seriously to undermine the strike as a collective bargaining device, does not qualify as a valid extension of the employer's rights under the Mackay rule. However, given the readiness of the courts to accept strike superseniority as not unlawful per se, and pending an authoritative ruling by the Supreme Court on the subject, it is submitted that its application should be limited to cases where the employer is able to show reasonable economic necessity and actual inducement of replacements as justification for the initiation of such a plan, and where he has informed the strikers of the plan prior to the termination of the strike.

${ }^{73}$ See text at note 69 sipra.

\title{
APPLICATION OF THE DOCTRINE OF RES JUDICATA TO SUCCESSIVE IN PERSONAM AND IN REM ACTIONS IN ADMIRALTY
}

A maritime lienor enforces his claim by a libel in rem against the vessel. ${ }^{1}$ If he also has a personal claim against the owner of the vessel for the same injury, as in cases of collision, he may proceed in personam, either at law or in admiralty. ${ }^{2} \mathrm{It}$ is generally held that the remedies in personam and in rem are cumulative rather than in the alternative. ${ }^{3}$

1 The Moses Taylor, 71 U.S. (4 Wall.) 411 (1866); The Hine v. Trevor, 71 U.S. (4 Wall.) 555 (1866). For an excellent discussion of the sources of maritime liens, emphasizing the role of the Federal Maritime Lien Act, see GIIMORE \& BLACK, ADMIrRALTY \$§ 9-30 to 9-43 (1954).

2 See GIIMORE \& BLACK, ADMrralTY $\$ 1-13$ (1954), for an interesting analysis of the principles involved in the problem of dual jurisdiction, including citation of the pertinent cases. Of particular importance to this question is the so-called saving clause, 28 U.S.C.A. $\$ 1333$ : "The district courts shall have original jurisdiction, exclusive of the courts of the states, of: (1) Any civil case of admiralty or maritime jurisdiction, saving to suitors in all cases all other remedies to which they are otherwise entitled."

${ }^{3}$ The Golden Gate, 52 F.2d 397 (9th Cir. 1931); The Grand Republic, 138 Fed. 615 (E.D.N.Y. 1905), aff'd, 144 Fed. 1022 (2d Cir. 1906); Morris v. Bartlett, 108 Fed. 675 (3d Cir. 1901); Rogers v. The Reliance, 20 Fed. Cas. 1125 (No. 12,019) (C.C.D. La. 1872); Baun v. The Ethel G., 125 F. Supp. 835 (D. Alaska 1954); The Henry S., 4 F. Supp. 953 (E.D. Va. 1933); The Eastern Shore, 24 F.2d 443 (D. Md. 1928); Everett v. United States, 277 Fed. 256 
Allowing the plaintiff thus to pursue first one remedy, and if unsuccessful either in obtaining a judgment or in satisfying a judgment acquired, then to proceed on the other appears to be inconsistent with the policy of res judicata, going under the rubric of bar, or merger, which would require the plaintiff to consolidate all remedies for a single cause of action in one claim. This branch of the doctrine of res judicata is "largely supported on the ground that public policy does not tolerate . . that a matter once adjucated should again be the subject of judicial inquiry." The plaintiff should not be allowed twice to vex the defendant on the same cause of action; nor should he burden the courts with unnecessary litigation. ${ }^{5}$

Judge Learned Hand, writing for the Second Circuit in 1954, challenged by dictum the established policy concerning successive in personam and in rem actions. ${ }^{6} \mathrm{~A}$ barge belonging to Burns Brothers, libellants, was damaged in a collision with a carfloat owned by the Central Railroad of New Jersey while it was in the possession of the Long Island Railroad. Burns Brothers first libelled both railroads in personam, and obtained a decree against the Long Island. ${ }^{7}$ The libel against the Central Railroad was dismissed on the ground that there was no evidence of its negligence. As the Long Island's assets were in the hands of a receiver, the decree against that road was of little value to the plaintiff. Burns Brothers then libelled the carfloat in rem; and the claimant Central Railroad pleaded the dismissal in the first suit as a bar to the second. Judge Hand accepted, by dictum, the contention that ordinarily res judicata would bar prosecution of the in rem action, ${ }^{8}$ but allowed the suit to proceed because he thought

(W. D. Wash. 1921); The Cerro Gordo, 54 Fed. 391 (D. Conn. 1893); The Brothers Apap, 34 Fed. 352 (E.D.N.Y. 1888) (dictum); Atlantic Mutual Ins. Co. v. Alexandre, 16 Fed. 279 (S.D.N.Y. 1883); Toby v. Brown, 11 Ark. 308 (1850). The difficulty arises when a damaged party seeks relief in an action in rem or in personam. After proceeding to judgment the plaintiff again brings an action in rem or in personam (whichever he did not pursue in the first action), because the former judgment is either totally or partially unsatisfied, or is adverse to him. A satisfied judgment is a bar to the second proceeding. Slepski v. Dravo Corp., 104 F. Supp. 89 (W.D. Pa. 1951). The owner of the vessel has the right to limit his liability for the injury complained of by proceeding in conformance with 46 U.S.C.A. $\$ \S 183-185$. He may thus limit the judgment to the value of the vessel. This limited judgment, when satisfied, is a bar to all future proceedings for redress of the same injury. 49 Stat. 1480 (1936), 46 U.S.C.A. $\$ 185$ (1952). If the plaintiff first seeks relief at law, limitation proceedings may be had in the federal courts. Larsen v. Northland Transp. Co., 292 U.S. 20 (1934); Ex Parte Green, 286 U.S. 437 (1932); Langnes v. Green, 282 U.S. 531 (1931).

${ }^{3}$ Adams v. Davies, 107 Utah 579, 584-585, 156 P.2d 207, 209, 158 A.L.R. 852, 856 (1945).

${ }^{5}$ See generally BLAck, Judgarents $\$ 500$ (2d ed. 1902).

${ }^{6}$ Burns Bros. v. The Central R.R. of New Jersey, 202 F.2d 910 (2d Cir. 1953).

${ }^{7}$ Burns Bros. v. Long Island R.R., 176 F.2d 406, 950 (2d Cir. 1949).

${ }^{8}$ In reaching this conclusion Judge Hand relied on two cases, which he described as ${ }^{x}$ holding a prior in rem action a bar to a proceeding in personam. Bailey v. Sundberg, 49 Fed.583 (2d Cir. 1892); Sullivan v. Nitrate Producers Ltd., 254 Fed. 361 (E.D.N.Y. 1918). While the language in these cases is ambiguous, the better interpretation is that the holdings in both cases go to the question of collateral estoppel rather than that of merger. It is somewhat difficult to extract even a definite dichum statement which would support Hand's position. Another inter- 
that perhaps the carfloat had not been available for arrest in an in rem proceeding when the libel in personam was brought. It will be noted that this is simply an application of the settled rule of res judicata that while a valid judgment or decree is conclusive upon the parties and their privies of all demands arising out of a single cause of action which were or might properly have been litigated in a single suit, those remedies not available to the plaintiff through no fault on his part may be asserted in a second action. ${ }^{9}$

The established rule allowing successive in rem and in personam actions was first enunciated in Toby v. Brown ${ }^{10}$ in 1850. The Arkansas Supreme Court held that a statute giving the plaintiff remedies both in rem and in personam was designed to afford two cumulative remedies for the plaintiff to obtain his satisfaction." Disturbingly absent is any indication of why this interpretation, apparently denying the application of res judicata, should be preferred over one which would give effect to that doctrine. The English cases on this point, dating from 1859, have reached the same conclusion on the basis of similarly unsatisfactory rationale. ${ }^{12}$

The most recent case restating the Toby rule came in 1954 . The District Court for the District of Alaska, in Baun v. The Ethel $G .{ }^{13}$ relied strictly on stare decisis in reaching its conclusion. The opinion quoted from an earlier case which stated, in effect, that the court felt the rule should be such as to allow two suits. ${ }^{14}$ Again no substantive reason for this result was given.

esting feature of the Burns opinion is Judge Hand's failure to rely on, or even cite, a decision of the Second Circuit rendered in 1941 which deals with some of the problems presented by Burns and decides the issues favorably to the Burns result. Judge Clark wrote the opinion; but Judge Hand was on the bench. See The B. \& B. No. 10, 121 F.2d 704 (2d Cir. 1941).

9 REstatement, JUDGMENTs $\$ 65$ (1942); and generally, 2 BLACK, JUDGMeNTs $\$ \S 731,732$ (2d ed. 1902).

10 11 Ark. 308 (1850).

"The statute in question reads as follows: "The plaintiff may make his election either to proceed against the owner or owners by their proper names, or by the name and style of their partnership, if known, or again such boat or vessel by her name or description only ...." English's Digest of Laws in Force, 1846 (Arkansas) ch. 18, $\$ 4$ (1848). The reader will note that the use of the words "election" and "either" would seem to indicate an intent to make the remedies alternative, rather than cumulative.

12 The Joannis Vatis (No. 2), [1922] p. 213; Five Steel Barges, [1890] 15 P.D. 142; Nelson v. Couch, [1864] 33 L.J. (C.P.) 46; The John and Mary, Swab. 471, 166 Eng. Rep. 1220 (Adm. 1859); The Bengal, Swab. 468, 166 Eng. Rep. 1220 (Adm. 1859). It is interesting to note that there is even less English authority on this problem than there is in the United States. Perhaps the difference in the theories underlying the law of maritime liens in the two countries explains this fact. The American law is said to be based, at least to some degree, on the fiction of the ship's personality, while the English law is grounded in what is called the "Procedural Theory," which apparently makes the in rem action on the maritime lien substantially the same as a quasi in rem action, where the goods are seized for the purpose of obtaining jurisdiction over thedefendant, here the owner of the vessel. See Hebert, The Origin and Nature of Maritime Liens, 4 TUL. L. REv. 381 (1930).

13125 F. Supp. 835 (D. Alaska 1954).

14 The Brothers Apap, 34 Fed. 352 (E.D.N.Y. 1888). 
There are several arguments which might support cumulation of the in rem and in personam remedies in the face of the doctrine of res judicata. First, it may be suggested that the ship and its owner are different "persons," that they should therefore be treated as joint tort-feasors, or joint contractors. It is generally held that an action against one party so liable is no bar to an action against the other unless a judgment obtained has been satisfied. ${ }^{15}$ This notion is suggested by the tendency of admiralty to treat the vessel as a person. ${ }^{16}$ While this would provide a theoretical path to the Toby result, it does not justify that result in pragmatic terms. Furthermore, the idea of personification seems to be losing favor because of its highly fictional character. ${ }^{17}$ After all, the vessel is the property of the owner. It is he who must defend a suit against it. It is he who stands to lose if the vessel "loses." The ship is at most the measure of the owner's stake in the dispute..$^{18}$ Judge Hand has described the personification theory as "archaic ... an animistic survival from remote times . . based on ... irrational fictions." ${ }^{\prime 19}$ Originally the idea seems to have been that the ship herself committed the tort; therefore she might be held liable as a person. ${ }^{20} \mathrm{It}$ would seem more reasonable to treat the vessel simply as security for the underlying debt of the owner, the operator or both. This would avoid misleading notions of personality, while retaining the protection of the creditor which seems desirable.

Admitting that the owner is really the defendant in both the in rem and in personam actions, it might be reasoned that the plaintiff really has two separate causes of action by virtue of his dual remedies. Yet, assuming the existence of both the maritime lien and the personal liability of the owner, in most cases the facts needed to support recovery in rem would be identical with those essential to recovery in personam..$^{21} \mathrm{~A}$ more significant indication that a single cause of

${ }^{15}$ For a brief discussion of the rule in the tort cases see Prosser, TORTS $\S 46$ at 242 (1955). The common law rule on this point that a judgment against one joint contractor operated to bar actions against others has been reversed by statute. See WuIISTON, CoNTRACTs $\$ 330$ (1938); Corbin, Contracts $\$ 929$ (1952); UnIForar Jornt Obligations ACr § 2 (1925): "A judgment against one or more of several obligors, or against one or more of joint, or of joint and several obligors shall not discharge a co-obligor who was not a party to the proceeding wherein the judgment was rendered."

${ }^{16}$ See note 13 supra. Justice Holmes notes this fact in THe CoMaron Law, 25 et. seq. (1881). He does much to impress with his distaste for the fiction in The Western Maid, 257 U.S. 419 (1922).

${ }^{17}$ See particularly Guxrore \& BLACK, AdMIRAIty §9-18 (1954). But cf. Canadian Aviator, Itd. v. U.S., 324 U.S. 215 (1945).

${ }^{18}$ See note 3 supra.

${ }^{19}$ The Carlotta, 48 F.2d 110, 112 (2d Cir. 1931). Judge Hand comments similarly in Burns Bros. v. The Central R.R. of New Jersey, 202 F.2d 910 (2d Cir. 1953).

20 Grimore \& Black, AdMrralty § 9-3 (1954).

${ }^{21}$ The Restatement of Judgments $\S 61$ (1942), states that when successive suits are brought by the plaintiff against the same defendant the cause of action is the same "if the evidence needed to sustain the second action would have sustained the first action." The Burns case is a good example of the exceptional case in which this test would not demonstrate clearly singularity of the cause of action. 
action is involved in these cases is the fact that the plaintiff has suffered but one injury. In the oft-cited admiralty case of Baltimore S.S. Co. v. Phillips, ${ }^{22}$ the Supreme Court stated that a cause of action is essentially an invasion of a single legal right by a single legal wrong. This definition appears applicable to the cases here in question. One injury, giving rise to both a maritime lien and a personal claim against the vessel owner, creates but one cause of action. ${ }^{23}$

A third rationale by which the Toby rule might once have been justified is based on the Admiralty Rules promulgated by the Supreme Court in $1842 .{ }^{24}$ Under those Rules it was impossible to join an action "against the vessel" in rem and a suit in personam against the owner. ${ }^{25}$ In this situation the exception to res judicata relied on in Burns ${ }^{26}$ might properly be used to avoid application of merger or bar. Two early cases seem to have relied somewhat upon this reasoning. ${ }^{27}$ In 1920 , however, the Rules were altered, ${ }^{28}$ and joinder is now widely permitted..$^{29}$ Since 1920 the cases have continued to apply the old rule, though at least this much of the underlying rationale is gone.

2274 U.S. 316, 321 (1927).

${ }^{23} \mathrm{An}$ excellent illustration of those cases in which the plaintiff has suffered a single injury and is entitled to but a single recovery is American Fire and Casualty Co. v. Finn, 341 U.S. 6 (1951). That case held that a plaintiff, due recovery if at all from only one of several alternative defendants, did not have separate and independent claims or causes of action against such defendants.

24 The interest is with the old Admiralty Rules 12,13,14 and 15, noted historically in Admiralty Rules 13 and 14, 28 U.S.C.A.

Rule 12. In all suits by materialmen for supplies or repairs, or other necessaries, the libellant may proceed against the ship and freight in rem, or against the master or owner alone in personam.

Rule 13. In all suits for mariners' wages, the libellant may proceed against the ship, freight, and master, or against the ship and freight, or against the owner or master alone in personam.

Rule 14. In all suits for pilotage, the libellant may proceed against the ship and master, or against the ship, or against the owner alone or the master alone in personam.

Rule 15. In all suits for damage by collision, the libellant may proceed against the ship and master, or against the ship alone, or against the master or the owner alone in personam. Rules promulgated under Act of August 23, 1842, c. 188, 5 Stat. 516 and amendments.

${ }^{25}$ The Corsair, 145 U.S. 335 (1892); The Tonawanda, 278 Fed. 391 (S.D. Fla. 1922)(dicta); The Steamship Zodiac, 5 Fed. 220 (S.D.N.Y. 1881); The Clatsop Chief, 8 Fed. 767 (D. Ore. 1881).

${ }^{26}$ See note 9 supra.

${ }^{27}$ Morris v. Bartlett, 108 Fed. 675 (3rd Cir. 1901); Atlantic Mutual Ins. Co. v. Alexandre, 16 Fed. 279 (S.D.N.Y. 1883).

${ }^{28}$ Rule 13. In all suits for mariners' wages or by materialmen for supplies or repairs or other necessaries, the libellant may proceed in rem against the ship and/or in personam against any party liable.

Rule 14. In all suits for pilotage or damage by collision, the libellant may proceed in rem against the ship and/or in personam against the master and/or the owner. 28 U.S.C.A. The current rules were promulgated by the Supreme Court December 6,1920, to take effect March 7, 1921, amended and supplemented, under Act of August 23, 1842, c. 188, 5 Stat. 516 and amendments.

${ }^{29}$ Galban Loko Trading Co. S/A v. The Diponegaro, 103 F. Supp. 452 (S.D.N.Y. 1951); Mosher v. Tate, 182 F.2d 475 (9th Cir. 1950); The Paul I., 59 F.2d 223 (W.D. Wash. 1932). The two exceptions to the liberal attitude toward joinder are found in Rules 15 and 17. The former requires actions for assault or beating to be in personam only. The latter requires that suits on bottomry bonds be in rem only. 
A fourth argument in favor of the general rule, which would apply only where the plaintiff proceeds first in personam and later in rem, is suggested by the Restatement of Judgments:

Although by the judgment the original cause of action is extinguished and a new cause of action is created, advantages to which the plaintiff was entitled with respect to the original cause of action may not be destroyed by the judgment. Thus, if a creditor has a lien upon property of the debtor and obtains a judgment against him, he does not thereby lose the benefit of the lien. ${ }^{30}$

Certainly this rationale would apply to the cases here under study. The lien is an incident of the plaintiff's cause of action which has features of peculiar value not attaching to a judgment in personam. ${ }^{31}$ To merge the greater security in the lesser security would appear to be harsh on the plaintiff.

The rule quoted from the Restatement also finds application in other fields, particularly in the land mortgage cases. It is generally held that a creditor holding a mortgage as security does not lose the advantage of his mortgage by proceeding against the debtor personally on the debt. ${ }^{32}$ The theory seems to be that security for the debt once given should secure the debt until it is paid, regardless of the fact that the form of the debt has been changed into a judgment.

There are two difficulties with this reasoning. First, the example of the land mortgage situation serves as much to undermine the validity of the Restatement rule as it does to support it. While it is true that this rule still has the support of the majority of jurisdictions, there appears to be considerable agitation against it. Three states, California, ${ }^{33}$ Montana $^{34}$ and Utah ${ }^{35}$ have passed statutes which consolidate the remedies of the mortgagee in one action. Three other states, New York, ${ }^{36}$ Michigan $^{37}$ and Nebraska, ${ }^{38}$ have statutes which accomplish nearly

${ }^{30}$ Restatenent, JudgMenis $\S 47$, comment d (1942). See also $\S 64$, comment f.

31 The most important of these features is the survival of the lien, even when the vessel is sold into the hands of a bona fide purchaser for value without notice of the claim. The Bold Buccleugh, 7 Moore P.C. 267, 13 Eng. Rep. 774 (1852); The Everosa, 93 F.2d 732 (1st Cir. 1937); The Everosa, 20 F. Supp. 8 (E.D.N.Y. 1937); The Cerro Gordo, 54 Fed. 391 (D. Conn. 1893). But for the stringent limitations placed upon this exceptional feature of the maritime lien see The Key City, 81 U.S. (14 Wall.) 653 (1871).

${ }_{22}$ Hughes v. Mt. Vernon Bank, 4 Ga. App. 23, 60 S.E. 609 (1908); Pappas v. Cappell, 297 Ill. App. 301, 17 N.E. 2d 537 (1938); Continental National Bank and Trust Co. of Chicago v. Chicago Builders Bldg. Corp., 283 Ill. App. 64 (1935); Matthews v. Davis, 61 Iowa 225, 16 N.W. 102 (1883); Lanahan v. Lawton, 50 N.J. Eq. 276, 23 A. 476 (1892); Patton v. Beech, 2 Tenn. App. 437 (1926).

33 Cat. Code of Crvir Proceddure § 726. See Appel v. Hubbard, 155 Cal. App. 2d 639, 318 P.2d 164 (1957). For further information concerning this statutory provision see 25 CaLIF. L. REv. 347, 469 (1937).

34 Mont. Rev. Code. tit. 93, ch. 60, §93-6001 (1947).

${ }^{35}$ UTAR CODE ANN. tit. 78, ch. 37, \$ 1 (1953).

${ }^{36}$ Crv. Prac. of N.Y. AnN., art. 65, $\$ 1078$ (Gilbert-Bliss 1944).

${ }^{37}$ MrCH. STAt. ANN., tit. 27, $\$ 27.1137,27.1138$ (1938).

${ }^{38}$ NEB. REv. STAT., ch. 25, §\$ 25-2142, 25-2143 (1943). 
the same results by making multiple actions so burdensome that they would ordinarily be impractical.

A second and more telling objection to the rule of the Restatement is that the plaintiff could save the advantages of his lien simply by joining the two remedies in one suit, when possible, as required by Burns.

A final argument in favor of the established doctrine is that application of res judicata as suggested in Burns would force the plaintiff to an "unjust" election. He must proceed at law and lose the benefits of his maritime lien (since it may be enforced only in admiralty), ${ }^{39}$ or in admiralty and lose access to a jury trial. ${ }^{40}$ This choice appears most harsh when the defendant, but for the vessel, is insolvent, the lien then having great value as a privileged claim to the plaintiff. Yet this seems not unlike the situation confronting the would-be purchaser of a tract of land who has paid the purchase money according to the terms of an executory contract. If the seller is insolvent except for the property in question, the buyer must "elect" either to proceed at law and lose the benefit of his privileged contract claim to the land, or to ask for specific performance in equity, where he cannot have a jury trial. It is easily seen that the effect of the Burns rule is not without precedent in other branches of the law.

It should be noted, however, that this conflict between the jury trial and the preferred claim to the debtor's remaining assets is not likely to arise, particularly in admiralty. If the plaintiff sees that the defendant is insolvent, or is likely to become so, he will immediately choose to assert his privileged claim, which must be heard without a jury. If the defendant is completely solvent the plaintiff will probably prefer the personal liability of the defendant, since the maritime lien is subject to divestment by subsequent liens. ${ }^{41}$ In this case the choice be-

${ }^{39}$ See note 1 supra.

${ }^{40}$ An interesting case involving potential election between multiple remedies and jury trial was The Four Sisters, 75 F. Supp. 399 (D. Mass. 1947). A seaman had been killed during the course of his employment on board the Four Sisters. The decedent's father then brought an action in admiralty as administrator, to recover in his own behalf, and for a brother and a sister. On plaintiff's motion, the action was transferred to the law side of the court. When the plaintiff attempted to introduce evidence of pecuniary loss to the sister, the court refused to admit it because, as it said, the law action must be under the Jones Act (49 Stat. 1480 (1836), 46 U.S.C.A. $\$ 688$ (1952)), which provides a remedy in these circumstances for the father only. The sister could recover only under the Death on the High Seas Act (41 Stat. $537(1920), 46$ U.S.C.A. $\$ 761$ (1952)). This action is exclusively within the jurisdiction of admiralty. The plaintiff then proceeded at law and judgment was entered in his favor, and was subsequently satisfied. Then a second action was brought by the father as administrator on behalf of the sister. This time the action was in admiralty under the Death on the High Seas Act. One of the grounds on which the court put its decision to allow the second separate action was that a contrary holding would force the plaintiff either to proceed at law and lose the benefit of the other remedy, or to go into admiralty, where he might proceed under both acts, but would lose the possible benefit of a jury trial. The court felt that this was too much of a hardship.

11 The general rule of priorities in the field of maritime liens is that the last in time is prior in standing. This rule is, however, perforated with many exceptions. For a good discussion of this problem see GILMORE \& BLACK, ADMIRALTY Chapter IX (1954). Discussion of this and related matters is scattered throughout the chapter. 
tween a jury trial and preservation of the lien becomes moot, since the plaintiff does not need this security for his judgment. This may explain why the courts have never relied on this reasoning to support the rule of the Toby and Baun cases.

If, for some reason, the plaintiff should complain of the election which, by the Burns rule he would be required to make, the result, while one involving policy considerations not simple to resolve, should nevertheless be clear. Given that there is no question of the Constitutional right to a jury trial in these cases, ${ }^{42}$ the policy of res judicata should weigh more heavily. If this were not the case, common law courts should refuse to accord res judicata effect to decrees of equity or admiralty courts generally in cases where the plaintiff could have sought his relief either at law or in one of these other courts.

On the whole there does not seem to be sufficient strength in the established rule to support it in light of the advantages which will accrue by the application of res judicata as in the Burns case.

42 The right to a jury trial is given only in actions at law. The plaintiff who elects to proceed in admiralty in order to secure advantages to himself not available at law cannot be heard to complain that he has been deprived of trial by jury.

\section{WORK-ASSIGNMENT DISPUTES UNDER THE RAIIWAY LABOR ACT}

Work-assignment disputes arise in the railroad industry when each of two unions claims that its collective agreement with a carrier entitles it to a particular job. The highly fragmented craft structure ${ }^{1}$ of the industry results in overlapping interests and a jealous guarding of position by each craft group against the inroads of others. When technological or other changes increase or reduce the available jobs, each union seeks to secure or preserve assignments for its members. ${ }^{2}$ This comment will deal with the issue of whether the resulting disputes are to be settled within the framework of the existing collective agreements or by renegotiation of these agreements. This issue arises largely from the unique features of both the tribunal provided by the Railway Labor Act for adjusting controversies growing out of the interpretation or application of collective agreements and the collective agreements involved.

${ }^{1}$ All attempts at industrial unionism in the railroad industry have failed, in part because of the hostility of existing unions toward potential rivals.

" 2 See Kauthan, Collective Bargatning in the Ratrroad Industry 45, 147 (1954); Garrison, The National Railroad Adjustment Board: 'A Unique Administrative Agency, 46 YALE L.J. 567, 590-91 (1937). 